\title{
Furrows in the Field, or Down in the Jungle: Re-membering Domestic Literacy in the Early Years
}

\author{
JOAN BARBARA TRAVERS SIMON \\ University of Luxembourg
}

\begin{abstract}
Embracing qualitative methods in an approach situated at the interface between education, social science and philosophy, the author offers a phenomenologicallyoriented account of a literacy event which took place in the home a five year-old girl in Alsace, France. The paper shows how the author plunges into the 'jungle' of reflections set off by the literacy event. In so doing, the paper not only seeks a fresh look at what educational researchers believe they see/understand, but it equally questions how such understanding is shared within the research community and beyond, thus it interrogates orthodoxies with regard to academic discourses and research methodology. The author proposes that to learn is to be in media res in the interminable flux of possibility. Learning is a never-ending story, which can only be told at a particular cross-section of time and place. Much follows from this insight, most importantly that attempts to understand and learn from learning, in addition to attempts to write academic readings of learning, may be more fruitful if we abandon not only measurables but equally product-driven analytical approaches in favour of processual ones.
\end{abstract}

\section{Introduction}

Embracing a qualitative integrative methodological approach by means of which I situate my work at the interface between education, social science, and philosophy, I offer a postmodern/structuralist, creative non-fictional account of a typical incident of family literacy. In so doing, and by performing ${ }^{\mathrm{i}}$ my initial grappling with the material, I plunge the reader into the everyday dynamics of a particular family. Rather than provide explanations of the interaction witnessed, I seek a fresh look at what I believe I have seen/understood and how I choose to disseminate my understanding.

When researchers observe situations in which children, via talk, display how they attempt to improve their understanding of a given phenomenon, we are, in fact, only observing a certain set of habits with words (Russell, 2008). For those accustomed to conventional academic papers, a consciously creative---as opposed to a purely invented---account of so-called facts regarding the performance of learning (both my own and that of the family) may at first feel uncomfortable. I, however, hope that such discomfort at my breaching of the implicit canonical script (Bruner, 1991) will incite reflections about assumed notions of data presentation and the consensus into which the reader is potentially lulled by more conventional research discourse and methodology; a discussion which is already vigorously under way within qualitative research (e.g. Denzin \& Lincoln, 2005).

My aim is to share the discomfort I felt with wandering so far from the beaten track; to show, and thereby validate the vulnerability which is inherent in an honest search for greater understanding, since such a search is driven by the confession: 'I 
don't know'. If we did, we wouldn't go looking. And if you go looking, you may very well get lost at a certain point. I seek to validate vulnerability, therefore, but also the giddy excitement that arises from the willingness to open up and entertain every possibility; a willingness to not bracket off our thoughts in advance, or pre-empt the direction they should/could take. This paper, therefore, should be read as a series of in-roads, of furrows in my thoughts, such as they are recorded in my logbook after trips into the field, or when I happened to get an insight at whatever time of day. The design of the paper is intended to allow the reader to watch me at work in a more authentic, more honest manner than is the case when listening to me impart truths from a podium with a powerpoint presentation to back up such 'scholarship from a safe distance' (Stoler, 1995, p.198); scholarship, craftsmanship which clears up the mess, the cud and debris of research 'lived' prior to its dissemination as research 'told'. In addition to the unusual structure and semantics of the paper, one of the techniques I employ to provide this close-up on the dynamism of perceived reality is to consciously play with different fonts, my point being to make the reader aware of shifts in my perspectives, and to generally draw attention not only to what the readers of this paper (think they) see, but to where such thoughts may be coming from. In this connection, for example, the use of questions marks and of the mathematical symbol for eternity $(\infty)$ to punctuate various reflections with regard to the dialogue between academic disciplines, analytical approaches, and the questions these throw up, can be seen to allude to the incessantly interrogative stance researchers may adopt (e.g. thought chain \#6); a stance which affirms research as an open system.

The paper is structured as follows: after setting out, in a cursory fashion, the context of my research field, I present a transcript of an everyday interaction that took place in the home of one of the families participating in my research. The interaction in question was not in itself geared towards literacy learning, but on this and several other occasions, the child used the event as a means to bridge various areas of her learning as she helped her mother around the home. The reflections I have after witnessing this event are presented/performed in a different font (courier) and woven into the description/narrative ${ }^{\text {ii }}$. I close the paper by recapitulating my key questions, followed by a final vignette before I elaborate upon matters of representation.

\section{The Context}

The interaction presented below took place at the home of one of the families I have been observing since 2009 in a study of domestic literacy practices. Building upon my research conducted in a bilingual French-German school in Alsace (Bursch, 2005, 2008; Travers Simon 2010a, 2010b; Bursch \& Simon, 2009), I now research kidwatch (Goodman, 2007) - selected children aged 5-8 yrs at home and in their respective schools in Alsace and Luxembourg with a view to putting the children's individual experiences into larger cultural and pedagogical contexts. The time spent with each family and in each school varies according to the availability and willingness of the adults and children concerned.

Data collection, using ethnographic methods, is informed by the following interlaced issues as they relate to individuals, sites, materials and interactional dynamics:

- identities (imposed, granted or taken)

- interactional processes, meanings and functions

- literate forms employed for/issuing from interactions 
- characteristics of the environment as a concrete literate space in relation to knowledge transmission and acquisition.

The above can be seen to converge into an overall enquiry into the pedagogical ideologies at work:

- Which literacy messages are being transmitted in/at this particular home and/or school?

- How is literacy performed in/at this particular home and/or school?

- Which identities emerge of the learners/young writers?

A word or two about the family in question (all the names have been changed). Zoé is a five-year-old francophone child living with her single mum and her older brother, Luc. She is in the second year of a bilingual French-German nursery school in her home town in Alsace. Her mother, Christine, is a shop assistant. The family meets for lunch every day. The lunchtime hour is one in which Zoé is often eager to share her experiences of the morning with her mother, who, although interested and keen to support her daughter's learning, is often pushed for time. Below, I present the transcript of a visit to the family on such a morning. I had spent the morning with Zoé at school and taken her home for the first time. Once we are in the kitchen, I set up my taperecorder and turn it on. A few minutes after our arrival, Zoé's mum, Christine, comes bustling in through the door.

The transcript reproduced below gives the details of the literacy-related episode and my initial reflections, hastily jotted down as I listened to the interaction for the first time upon my return home.

Are you sitting comfortably? Then let us begin.

\section{Entering the Field: So, What's Cooking?}

Zoé $(\mathrm{Z})$ helps her mother, Christine $(\mathrm{C})$, to lay the table:

$1 \quad \mathbf{Z}$ Today it's my turn to lay the table. Luc did it yesterday.

2 (Goes to the drawer to fetch the cutlery)

3 C (Without looking at the child) Well go on then!

$\begin{array}{lll}4 & \mathbf{Z} & \text { (Counting the forks as she takes them out. Taking her }\end{array}$

5 time): Zoé ... Luc ... Mummy... (Counting the knives as 6 she takes them out):

7 Zoé ... Luc ... Mummy...(She tries to carry all the

$8 \quad$ cutlery in one go, then decides to group all the knives in one hand and all the forks in the other.) Where's my marker?

9 C (Over her shoulder) Isn't it in the drawer?

10 Z No!

11 C Then it must be in the dishwasher

$12 \quad \mathbf{Z}$ (Looks at her hands full of cutlery, then puts them all down. Thinks for a moment) Blue to the left... blue... to the ... left...(Picks up forks with her left hand): Red to the right... to the right... (Then the knives with her right hand)

16 C See, you don't need your marker anymore then, do you?

$17 \mathbf{Z}$ Yes I do. In case I forget! (Laughs, looking at her mum)

Luc is on his way home.

He takes the bus

$C$ has to get back to work. Lunchtimes are often rushed

I think of the 'put in groups' exercises done at school...

What's this?

NB no eye contact

Marker in the dishwasher???

NB physical mobility. Zoé moves around a lot 
C (Her back still to the child) If you forget, then think about the rule. Blue...

$\mathbf{Z}$ To the left (looking at the forks)

C ...to the left... that's right... Red...

$\mathbf{Z}$ (Holding up the knives) To the right. (Puts the cutlery on the glass table, noisily)

C (Turns around) Where are the tablemats?

Z I'm going to get the tablemats. (Goes to the buffet and opens a drawer. Takes the tablemats) Zoé ... Mummy ... Luc (stands briefly in front of Luc's place, thinking)

C Don't forget two for the middle. And if you're not sure where to put them, then just sit down where that person would be sitting, and work out where's your left and right. That way you won't get them the wrong way round.... especially for Luc... Don't forget the-

$\mathbf{Z}$ Two for the middle. (She fetches two more. Her face lights up) Mum, two plus three makes five!

C Very good Zozo. And how many knives and forks have we got?

$\mathbf{Z}$ (Pointing at the pile of cutlery): One ... two ... three ... four ... five ... six. Six!

C Great. Here. (Turns round to give Zoé two big serving spoons.) Put 'em in the middle (impatient)

$\mathbf{Z}$ (Zoé places the spoons in the middle of the glass table, noisily.)

C (Turns around again at looks at Zoé crossly)

$\mathbf{Z}$ (Rolling eyes) Oh! (Puts two tablemats in the middle of the table, and then the spoons on the mat.)

C (Wiping down the worktop and putting ingredients away quickly) How many have we got now?

Z Two.

C (Stops. Looks at Zoé.) Two what?

$\mathbf{Z}$ (In a self-explanatory tone, and pointing at the spoons) Two spoons!

C I mean altogether.

Z (Looks at her mum, incredulously) Everything altogether?

C (Exasperated) Only the cutlery.

$\mathbf{Z}$ (Pointing) One ... two ... three ... four ... five ... six ... seven eight!

C Excellent. (Scrapes the vegetable peels into the bin.)

$\mathbf{Z}$ One, two, three, four, five, six, seven, eight! Eh mum, five is like an $S$. A little bit, isn't it, mum?

C Yes.

Z And eight is like two $S$ s kissing each other. (Draws an $S$ on the table, laughing)
I've seen the worksheet done at school to train this

Question or imperative?

Bridges over into maths

Initiation-responsefeedback

???

Cf scaffolded letterwriting exercises at school: almost the same mvmt. 5 is not the same as S

Cf mirrored writing of S: check to see how often Zoé does this during this year. Anthropomorphizes the letter S. Why do I say draw and not write???

Like prewriting activities, 
How do you do? I'm very cold-

65 C (A bit stern) Zoé, the tablemats.

$\mathbf{Z}$ (Putting the tablemats in place, singing):

Would you like a hat?

Yes thank you!

Would you like a scarf?

(No longer singing)

$\mathrm{S}$ and $\mathrm{Z}$ are almost twins, aren't they mummy?

C Hurry up, Zoé.

$\mathbf{Z}$ (Puts the knives and forks in place, talking to herself.

Looks at her mum) Okay?

C (Looks round) You need enough space for the plate in the middle.

$\mathbf{Z}$ (Pushes the knives and forks to the edges of the tablemat) Give me the glasses.

C (Takes the glasses out of a wall cupboard and passes them to Zoé one by one)

$\mathbf{Z}$ (Places each glass on the worktop, then takes them to the table individually.) Can I help make the drink?

C One minute. Get the serviettes whilst you're waiting

$\mathbf{Z}$ (Tears off three pieces of kitchen paper, folds them in half and places them beneath the knives.) It's not really in the middle...

C (Without looking) It's fine like that. I'll show you how to make a fan later. Some other time.

Z Yeah! Are you ready now?

C (Taking a pot off the cooker) Get the syrup.

$\mathbf{Z}$ (Brings a bottle of syrup and opens it)

C (Watches to see if Zoé can manage alone, then gets a jug.) Tip it up slowly!

$\mathbf{Z}$ (Tips the bottle very slowly)

C (Watching. Moves the jug so that the syrup is poured into the middle.) Okay.

Z I'm going to pour the water! (Pulls a chair to the sink. Climbs on it and turns on the tap)

C (Places the jug under the tap) That's enough!

$\mathbf{Z}$ (Turns off tap. Signals that she wants to carry the jug by reaching for the handle)

C (Pulling the jug slightly to herself) I'll do it. It's too heavy for you. (Carries the jug over to the table.)

$\mathbf{Z}$ (Follows mum, holding hands beneath the jug)

C (Places it on one of the centre tablemats. Says in a tone of relief) So. (She moves as if to reposition the glasses,

106 then waves a hand as if to say 'it doesn't matter') I'll do 
The interaction between mother and child documented above is over so quickly. When I observe Zoé laying the table for three and not four people, I realize that Christine has forgotten that she had invited me to lunch and had agreed to spend some time with me afterwards so that we could talk about her daughter's language and literacy development. Without mentioning this, I simply ask her if she would have some time for me if I came back later that afternoon. She informs me that has something else planned. It is not a problem. A few words are exchanged with mother and child, then I withdraw discreetly. As I throw my bags onto the passenger seat and head home, I think: and now, for me, in a sense, the real work begins.

\section{Re-Presenting and Re-Membering: Getting Inside the Messages}

When we wonder about 'what does it mean', we start the narrative engine for an inferential walk (Mininni, 2008, p.254, referring to Umberto Ecco's inferential walk)

Here I would normally launch into a detailed analysis of the 'data'. A traditional analysis is, however, inappropriate for the nature of this paper, which does not seek to explain, but to share the interpretive process. With this in mind, I will simply re-introduce the key questions at the back of my mind as I accompanied Zoé home, and follow these through with thought-chains of selected core reflections before I close this section with a vignette; not one of my own, this time, but one of an admired colleague from the U.S., Lesa Lockford, who has granted me permission to include her hitherto unpublished piece, Between the Pointed and the Soft.

Thoughts upon entering Zoé's home:

- Which literacy messages are being transmitted in/at this particular home and/or school?

- How is literacy performed in/at this particular home and/or school?

- Which identities emerge of the learners/young writers?

Thoughts upon leaving Zoé's home (on this and other occasions):

\section{Chain \# $1^{\text {iii }}$}

Work. Play. Bourdieu. Being. Emotion. Bernstein. Cognition. Piaget. Practitioner. Apprentice. Kress. Home/school. Drawing. Fereirro. Identities. Grapheme-phoneme. Text. Engestrom. Gender. Meanings. Bahktin. Colouring. Mercer. Front/backstage. Säljö. Inter/intramental. Street. Handwriting models. bruner. Scaffolding. Wood. Becoming. Dyson. On/offtask. Intertextuality. Von Bertalanffy. Multi-modality. Dewey. Social. Processes. Mead. Evaluation. Vygotsky. Shared spaces. Functions. rogoff. Framing. Chronotopes. Montessori. d/Discourse. Writing. Developmental niches. bronfenbrenner. Time... 


\section{Chain \#2}

On my 'spacious singing flesh' (Cixous, 1986, p.88) before it is overrun with words, I 'feel' these ideas swimming, bubbling up simultaneously. Have to go back and detangle them, name them one by one. As I nail them to the page to prevent their escape, new thoughts sprout up. Scribble them down, wherever. Add on later, I literally, physically 'feel' my thoughts growing (embryonic? cells? each new thought leading to a burst of new associations (viral?). Impossible to capture them, to tame them, all, in a single session. On paper is only what did not get away. Re-readings do not result in identical associations (my mind has the last laugh), so how true is this idea of equifinality (e.g. Sato, 2009, also my critique of equifinality in Travers Simon, 2010b, also Gottlieb, Wahlstein \& Lickliter, 1998)??? No matter. It is exciting to 'do', to observe myself doing so (observe the observer observe). Thoughts yield images: plasma, confetti, dynamic, unpredictable, ineffable, jungle. Nothing should escape. I cannot but fail... (11/07/30 05:00h, updated $12 / 02 / 1011: 05 \mathrm{~h})$

\section{Chain \#3}

'How can you help if you don't tell the right story?' (Jack to his younger brother, J.R. (Johnny Cash), in the film 'Walk the Line'). The right story? The right story??? Can I judge the rightness of my story? One story told to 20 listeners yields: 20 stories... (take another look at Vivian Paley, 1990, 1997...) (11/06/25 11:36 a.m.)

And why do we always say reading and writing and not writing and reading? To read is to 'write'; to construct an understanding... to read is to 'write' and what we write down is only ever one of potentially countless 'readings'; skilled manufacture, continually repaired... to read is to 'wright'... (11/08/03 04:14h)

'There is no such thing as getting it 'right', only 'getting it' differently contoured and nuanced' (Richardson \& St. Pierre, 2005, p.962) (11/08/17 17:45h)

\section{Chain \#4}

...children(learners) as teacher (and as researchers): I learn from them and must learn from them before I can 'teach' them anything (of use). Uni-directional postVygotskian research (e.g. Hoogsteder, Maier \& Elbers, 


\begin{abstract}
1998), neither adequately accommodates the bidirectionality of the teaching-learning process nor the interpersonal variables of the participant characteristics such as self/other/task perception (Light \& Littleton, 1998). A focus on interactive styles stressing knowledge reproduction at the expense of knowledge invention, leaves the learner disenfranchised. Researcher (me) as learner more than teacher. Teacher/learner roles in the adult/child dyad co-reside reciprocally and are forever shifting, shuffling, renegotiated (Travers Simon, 2010b). If I publish, then surely because I have 'learnt' something I want to share. Be aware of my own ZPD. Funny; the more experienced 'other' (Vygotsky, 1978) who stretches me to new states of understanding is the child who is classically positioned as knowing less (d/Discourse... ways with words...). So, how do the children 'tell it'? (11/07/30 $10: 04 \mathrm{~h})$
\end{abstract}

\title{
Chain \#5
}

Thought-chains... chained in (prisms of) thought... capture... torture... escape... freedom... of thought... can anything cast in language be 'free'? Why? Why do I do this (torture?)? What (who???) is it I am looking for (at???) ? Truth?

'What, then, is truth? A mobile army of metaphors, metonyms, and anthropomorphisms - in short, a sum of human relations which have been enhanced, transposed, and embellished poetically and rhetorically, and which after long use seem firm, canonical, and obligatory to a people: truths are illusions about which one has forgotten that this is what they are; metaphors which are worn out and without sensuous power; coins which have lost their pictures and now matter only as metal, no longer as coins.' (from Nietzsche (1873), On Truth and Lies in an Extra-Moral Sense, translated by Kaufmann \& Breazeale (n.d.), para 9, available online)

In speaking of lies, we come inevitably to the subject of truth. There is nothing simple or easy about this idea. There is no 'the truth,' 'a single truth' - truth is not one thing, or even a system. It is an increasing complexity. The pattern of the carpet is a surface. When we look closely, or when we become weavers, we learn of the tiny multiple threads unseen in the over all pattern, the knots on the underside of the carpet. (Rich, 1979, p.187)

Truthfulness anywhere means a heightened complexity. But it is a movement into evolution (Rich, 1979, p.187) 
I repeat: what is it I am looking for? A truth? Many truths (though I claim not to)? Truth/s (i.e., to scratch the positivist itch) is/are anticipatory in character. We lie in wait for them, but to lie in wait is one of the original meanings of the word 'fear'/faron... Anticipation constitutes a danger for reflexive, critical research since it means that conclusions have already begun to be massaged into place, which in turn renders us potentially blind to unforeseen eventualities wherein might precisely lie (some of) the answers to (some of) my questions... No Truth, then, whose very idea predicates upon a stability where there is nothing but change, for we cannot live outside of time and we live time in space. I speak of 'is' - of 'what is it?' - but the very word, or any other (and thus this entire paper), has me caught in a lie. The language lie (over and above the ontological trap). Language does not reflect (anything other than (certain aspects of) mind). Language creates: illegitimate life? It 'is' the sire of humanity's most cherished bastard; an existence which does not exist outside of my creation, thus outside of my language, thus outside of the lie. Immaculate conception! We are, all of us, with child. Deceivers all, and dirty, in spite of ourselves... the chains jingle. And I dance, drenched, reflected, refracted in the prisms of thought, techni-coloured, mind-coloured, my mind, let us be honest about that, seeking you, finding instead, with my bastard in arms, but layers of Me (11/08/11 19:00h, updated 11/08/17 17:21h, updated 12/02/06 15:25h)

\section{Chain \#6}

Threads thought $(\mathrm{s})$ bare/bear... $\infty$ ?counterhegemonic? $\infty$ ?reenactment? $\infty$ anthropology $\infty$ ?who/where is the protagonist? $\infty$ sociology $\infty$ ?narrative enquiry? $\infty$ ?anthropological poetics? $\infty$ (auto/performance) ethnography $\infty$ ?perspectives? $\infty$ ?bricoleurs? $\infty$ ?tricouleurs (true colours?)? $\infty$ ?deconstruction? $\infty$ education $\infty$ ?roots? $\infty$ ?routes? $\infty$ ?(in communication inheres) Noise $(\mathrm{N}=\infty)$ ? $\infty$ ?voice? $\infty$ ?postmodernism/structuralism? $\infty$ ? under whose aegis? $\infty$ ?hermeneutics? $\infty$ ?crystallization vs triangulation? $\infty$ ?systems theory? $\infty$ cultural psychology $\infty$ ?différance? $\infty$ ?erasure? $\infty$ ? where is she taking me? $\infty$ (socio) linguistics $\infty$ ?co-ordinate? $\infty$ ?paradigms? $\infty$ ?elision? $\infty$ humanities $\infty$ ?postpositivism? $\infty$ ?dance? $\infty$ ?borderlands? $\infty$ ?neo/realism? $\infty$ ?axiology? $\infty$ ?holistic interactionism? $\infty$ ?relativism? $\infty$ ?quasi/non/foundationalism? $\infty$ social sciences $\infty$ ?reliability? $\infty$ ?(in thought inheres) Doubt $(D=\infty)$ ? $\infty$ ?internal/external validity? $\infty$ ?creatively applied processes? $\infty$ ?art $<>$ politics? $\infty$ ?re-inscription? $\infty$ philosophy $\infty$ 
?postinterpretive? $\infty$ modern dynamic structuralism... knit one, slip one, pass slipped stitch over... does it fit???

...

life has forsaken you

only voices remain to remind

you

multiplicity enlightens the

path ...

(...)

you $-I-$ us

we are alone

so tightly locked inside my head

(...)

and in a dry riverbed

you let your thoughts

wander lazily lightly

in a language you have as of yet

to understand

and one day you might join them

hand in hand thoughts and you

swaying like a coracle off the shore

your thoughts blinded by the halo

and long forgotten feelings erupt

creep along hidden paths of your mind

in a language you wish you could understand

back in the past these feelings remind

you - the stranger you were

the stranger you are

estranged you always will be

(Sophie Gitzinger, Untitled, donated to Joan Barbara Simon August 19, 2011)

\section{Chain \#7}

If new thoughts grow out of (dissatisfaction with) old ones (the origin of evolutionary change = embryonic anomaly according to st. Hilaire, as cited in Buklijas \& Hopwood, 2008-2010), is this the organism adapting to its environment or indeed creating a new one? From a constructivist standpoint, an anti/post-ontological standpoint, there is no reality, but that we make it. (IS, that dirty word again, and me in the trap...). Environment is thus not outer, for humans, but essentially inner (thus contesting the argument that development originates from a resistance to external change, e.g. Valsiner, 1997), and its modification is an act of self-ingestion, of the mind eating itself... 
devouring the offal (excrement? fruit?) of its most cherished, yet illegitimate, babe in arms... tapeworms eating their way through the paradigmatic plasma of their own making. Eating themselves. Knit one, slip one, pass slipped stitch over... I knit together my reality, created anew, ever evolving as I worm my way through the loops left in the wake of former reflection. In thought inheres porosity; the soil for the further growth of this autoingesting organism (11/08/18 03:41h)

\section{Chain \#8}

Thought generates thoughts and as I desperately try to catch each one - how to, when a single thought generates a dozen others, generating a dozen others - the chase, chafing under the pretentious boundaries erected around my mind, breaks free to colonise my entire being; spills (erupts/ejaculates?) from my head to lava through my entire body, plunging me into the thickest jungle where I was in search of light. Derrida, you are right; and I, undone. Deferred. Différant, with no end in sight and no way back to a beginning that cannot be traced. It is my body that knows this, that feels this: post-cerebral epistemological crisis. Mind, salacious, overfed, sweaty, takes hostage my other continents. Intra-colonialism? Cogito-colonialism? Endo-colonialism? Language, being mine, I may do with it as I wish, but what has it done to/with me? The master enslaved. But as any imperialist will have me know, it is for my own good...

Whether the catalyst for such reflections was literacy or a judo class now seems by the by. I have 'thought' my way a long way from the classroom and from Zoé's home. Or have I possibly thought/fought my way back in through a different door? Starting out in the classroom/home, where am I now? Starting out by listening to the voices of others - Zoé, Christine, other children, parents and educators - what/whom is it I am listening to now, if not to the din of my own confusion as my ideas, my understandings resist coalescence into something coherent, something worthy of being called an answer? Reason as a practical tool has led to the traditional notion of academic responsibility that is tied to the pursuit of truth via conceptions of science based on the teleological orientation of intellectual labour toward the production of tangible outcomes (Trifonas (1996), in Trifonas \& Peters, 2004, p.32). Also: van Lier, 2004, 
p.200 - scientific proof as ocular, truth as verbal phenomenon. See however socratic argumentation - known as elenchus - deductive reasoning as 'proof' (e.g. in Caminada, 2004, 2008). I hear 'this'; nothing but the noise of my own thoughts in the jungle of strategies, theories and paradigms whose membranes have dissolved into a viscous swamp, and I think that, perhaps, I have thought the key protagonists - the children, their voices/learnings - out of the meta-interpretation. My voice is not strong but loud; not a voice from nowhere in the positivist tradition, but a voice going who knows where for now???

I stack, precariously, my newly, self-made, critically subjective building blocks with as much fascination, as much concentration, as any toddler. Curiosity impels me to knock them down and build them anew. A new constellation. Anew. Constellation. Anew. And to occasionally select one for the closer inspection of my still clumsy fingers, or my fresh, sore teeth. Maybe this is precisely where I need to be in order to see you more clearly (11/08/18 09:33h)

\section{Chain \#9}

No paper, no pen, but there is nonetheless a text, or texts. Social, verbal, semiotic, affective. Personal experience used to understand text better (life-to-text) and text used to grasp various facets of personal life (text-to-life) - Martinez, Roser \& Dooley, 2003. Modern dynamic structuralism (the analysis of stability/order within variation): $B=f(P, E)$ : Behaviour (B) equals individual functioning (f) that results from the interplay of Person (P) and (shouldn't that be 'in'???) Environment (E) - Magnusson \& Stattin, 1998. Orchestrate linguistic, temporal, spatial heterogeneity - Lemke, 2004 $(11 / 09 / 01$ 18:59h)

\section{Re-Flexing and Re-Membering Reflexivity}

Reflexivity "is a conscious experiencing of the self as both inquirer and respondent, as teacher and learner, as the one coming to know the self within the processes of research itself" (Guba \& Lincoln, 2005, p. 210). Regarding the embodiment of knowledge and summarising the work of McLaren on critical pedagogy, Alexander details that 'the body is the site of knowing and feeling, and the site from which transformation is instantiated and initiated' (Alexander, 2005, p.425). Regarding the image of the toddler with her building blocks, although the passage appears to echo a Nietzschean observation, it was thought up independently and prior to any reading of Nietzsche, of which the passage in question, on the creative pleasure 
of the free intellect, according to the translation by Kaufmann \& Breazeale (para 15, available online), reads as follows:

That immense framework and planking of concepts to which the needy man clings his whole life in order to preserve himself is nothing but a scaffolding and toy for the most audacious feats of the liberated intellect. And when it smashes this framework to pieces, throws it into confusion, and puts it back together in an ironic fashion, pairing the most alien of things and separating the closest, it is demonstrating that it has no need of these makeshifts of indigence and that it will now be guided by intuitions rather than by concepts.

(Friedrich Nietzsche (1873). On Truth and Lies in an Extra-Moral Sense. Translated by Walter Kaufmann and Daniel Breazeale (n.d.). Para 15)

Nietzsche goes on to distinguish between the rational and the intuitive man, noting that the latter (who scorns abstraction as much as the former fears intuition) is characterized by the willingness to play with seriousness. In the word seriousness resides a double entendre orbiting around distinctions between degree and kind: a) an adverbial connotation of playing seriously (i.e. degree) and b) an accusative connotation; seriousness (the noun), being the object or tool with which is being played (i.e. kind). Thus play, both as a tool and as a state, is, in the first instance, a creative, intuitive (serious) process. As Zoé plays with concepts, with the figurative qualities of letters and numbers, finding her own words to class their distinctions, defining each in relation to the other (take another look at de saussure and Derrida) - Zoé's only five but she's 'got it'! so quickly...), and thus exhibiting awareness of the contextualized nature of knowledge (meaning is adjunctive in the sense that it arises in relation to what came before and what comes after, e.g. Bahktin, 1981), she throws these observations over her shoulder for her mother to catch and appears to have to work much harder at figuring out where to put the knives and forks, or at making the squash. Does that not seem peculiar? So many different paces in this performance, this local episode. What, then, means 'quick'? What means 'slow'? The words have no meaning in themselves...

A word of caution: thought-chain \#1 suggests a sequential development of ideas - a view I do not, in fact, embrace. A web (tissue? pool?) of intertextual learning cells would be more appropriate (for a critique of the biological analogy, see Travers Simon, 2010b). What might such a learning cell look like? 


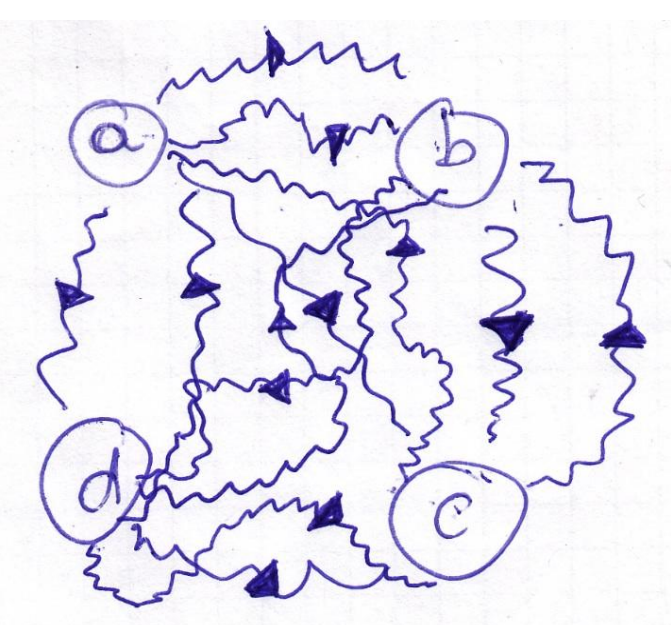

Figure 1. An organic cell.

In short: it looks complicated! (see Marcus \& Fischer (1986) on 'messy texts', cited in Guba \& Lincoln, 2005, p.211. See 'lawful but unpredictable' in Magnusson \& Stattin, 1998, p.687. See notion of 'constructive web' in Fischer \& Bidell, 1998. See Lemke, 2004 (online): 'lived worlds are not the worlds of official cartography'). Indeed, such complex, 'messy' processes - ambiguous conditions of possibility - have been identified as the source for later elaborated, structured thought, which Michel Foucault terms connaissance (translated as formal knowledge. A very accessible account of Foucault's work is provided by Scheurich \& McKenzie, 2005). In an earlier research project on literacy practices in Luxembourg, Frisch came to the same conclusion regarding the complex, intertextual conditions of possibility (Frisch, 1997). Below, Frisch's depiction of how knowledge is potentially interwoven or webbed in the case of stories: 


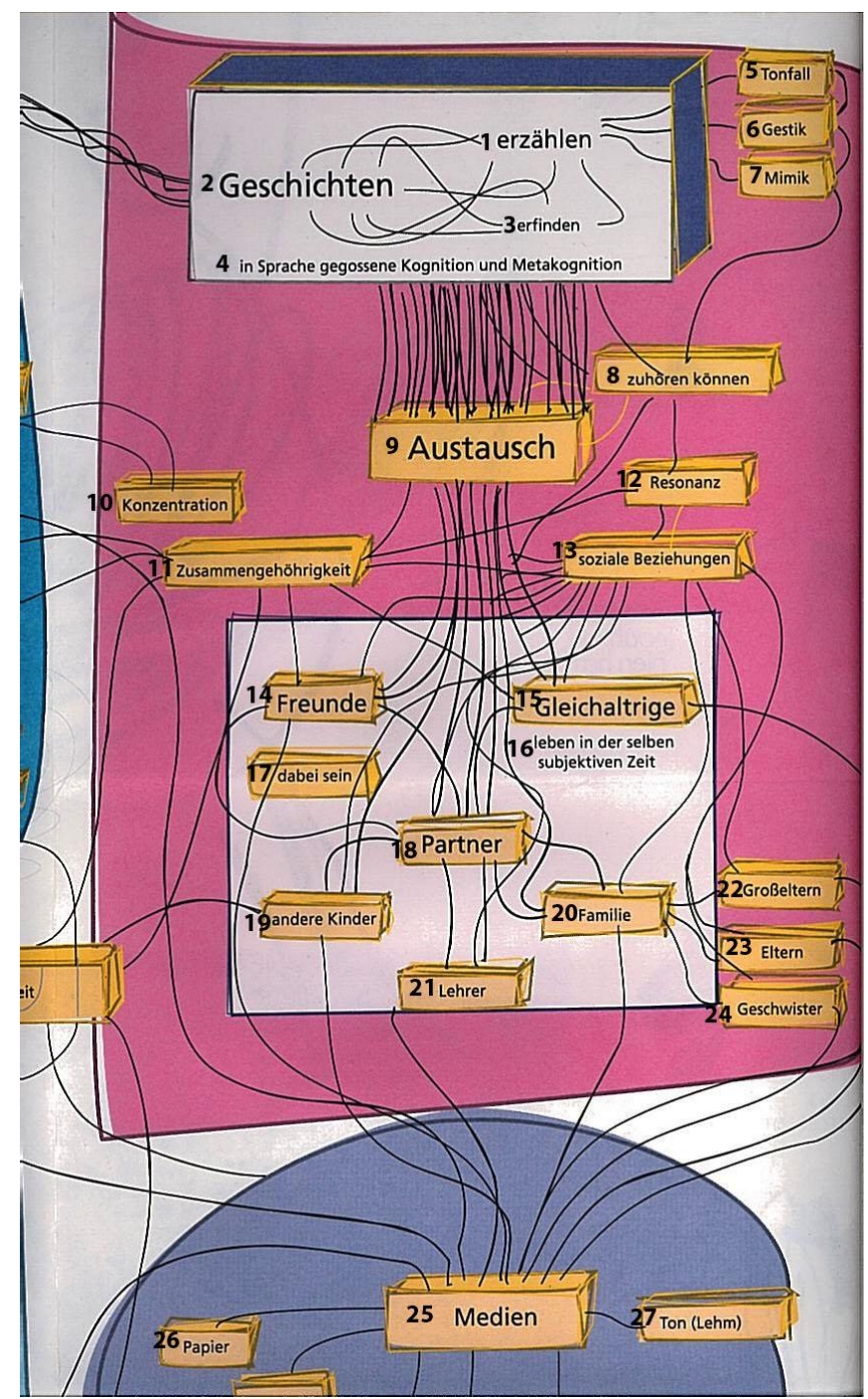

Figure 2. Knowledge networks in stories, From DECOLAP project, University of Luxembourg, Frisch (1997).

Key: 1:narrate 2:stories 3:discover/invent 4:cognition and metacognition cast in language 5:intonation 6:gestures 7:mimicry 8:being able to listen 9:exchange 10:concentration 11:belonging (e.g. to a group) 12:resonance 13:social relationships 14:friends 15:peers 16:living in a common subjective time 17: being there, participating 18:partner 19:other children 20:family 21:teachers 22:grandparents 23:parents 24:siblings 25:media 26:paper 27:clay

Telling the same story. Using different words... both trying to get it 'right'. Robert Stake (2005), discussing case studies, draws attention the earlier research of the Spiro group (1987) attesting to the illstructured (i.e. lumpy or non-isomorphic) nature of personal experience, both at the pedagogical and epistemological levels. Stake goes on to comment: 'it follows that a well-structured, propositional presentation often will not be the better way to transfer experiential knowledge' (p.456, italics in the original).

In keeping with an organic perspective, one might say that learning cells may die or become dormant. Also: the dynamic bi-directionality between/within a cluster of thought nodes (depicted here as a,b,c,d) which comprise learning cells may take 
different trajectories to the same ends (i.e. equifinality) with some paths possibly getting interrupted (lost? sealed?) or reconstituted differently, as learning strategies evolve. The pathways from one node to another are not to be conceived of as isomorphic, fixed or straight (no straight lines in nature):

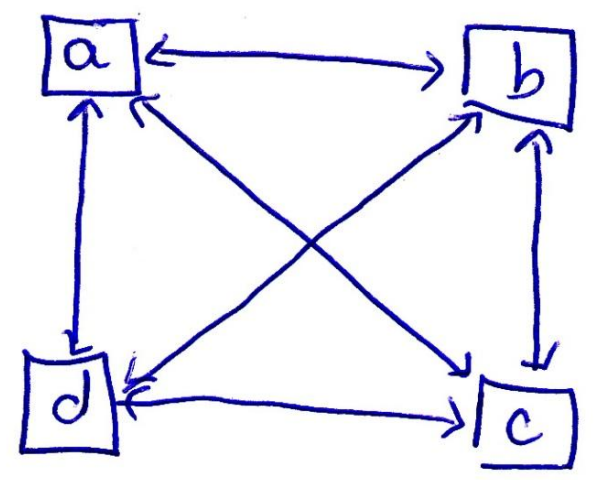

Figure 3. An isomorphic cell.

Spaces in between the nodes are not empty cognitive spaces (what are they filled with? General (stream of) consciousness? I think of water, with bubbles in it... back to the idea of plasma, of pool... 'thoughts yield images'...). If a 4-node cell already yields a complicated picture (can replace a-b-c-d by any of the mentions in chain \#1 and interconnect: e.g. on/offtask, framing, Kress (2003), Engeström (2001)...), just imagine trying to web all the ideas listed in the thought-chain \#1 above, which are but a few... Learning, and thus research (children are researchers...) is knotty; much knottier than the signs we entrust to paper as testimonies of cognitive performance when we 'do' (certain forms of) literacy. Any sign (e.g. oral, written, body language, etc) is but a trace, a congealed 'tool' (look up Latour?); an edit, never the whole truth. The ability to grasp the whole truth, as said, is pure illusion (Nietzsche?), positivist debris; a longing for that constant which will effectuate a peace of mind where otherwise we are left with - and in pieces. No truth 'in itself', for the sign is at once intertextual (Bahktin, 1981, also Derrida, 1976...), diachronic and synchronic, restrictive, elusive, incomplete... misleading... mendacious? The 'story' of learning never ends (and it can never be told 'right'); it is an open, dynamic (von Bertalanffy, 1962) a 'breathing' system (Travers Simon, 2010b): an infinite, rhapsodic journey, a dance, defying, if not mocking, the prescriptive, 'isomorphic', ambitions which persistently underlie research in general (qualitative research not exempted), to say nothing of definitions and/or semiotic representation in particular. 


\section{Snapshot: Literacy Across the Pond: Between the Pointed and the Soft by Lesa Lockford}

'I want to write this story but I don't know how to write. I'm not sure it can be written, because I do not know the end and because I do not know how to erase what's come before.

"I can't explain it," she said, sighing with evident exasperation. "Your daughter doesn't know how to write." You see, Mrs. Esselinger, my kindergarten teacher, had called my mother in for a parent/teacher conference. Nothing she tried to do, she said, was able to reach me. My mother, who sat opposite my teacher with numerous scribbled pages between them, listened for the words that would rewrite my future.

It was unexplainable. After all, I had come to Mrs. Esselinger a happy, rambunctious child. I had up until then always been, well, best described as "rambunctious." Not a beautiful child. A child with perpetually scabby knees. A child with tousled hair that was so frequently matted I routinely tested my mother's patience with a hair brush. So rambunctious that even when I was in the womb the doctor was moved to declare with simple efficiency, "it's a boy." Being born before the advent of ultra-sound and amniocentesis the doctor's simple sentence made sense to my mother, for you see, her pregnancy with me had been nothing like her first. A name was even chosen. I was to be Steven. Her first child, my sister Susanne, who writes her name with two Ss and no Zs, who arrived five years before me, had come into the world easily and beautiful. She'd always been the angel child. By the time I came into the world, my sister, the blond-haired child with eyes so blue and wide you could see the face of God in them, had a line of straight A report cards, a line that continued unbroken right through high school without a $\mathrm{B}$ or a $\mathrm{C}$ or a $\mathrm{D}$ or an $\mathrm{F}$.

So as my mother sat across the table with Mrs. Esselinger, pondering the inexplicability of my inability to write, she had no words ready to hand. write."

"I can't explain it," my teacher said. "Your daughter doesn't know how to

You see, to "graduate" from kindergarten we had to know how to write our names. I loved Mrs. Esselinger. I loved her as she marched down the schoolroom aisle dispensing onto our desks those pulpy pages for writing. Those pages with the wide lines on them, a line on the top row that guided the size of our capitals and the height of our verticals, and a dashed line below marking the destination of the curves of our As, Os, and Rs and so on. I loved her as she told us to grip our pencils in our hands, the soft end of the eraser up and the pointed end down and to hold them just so. If we made a mistake the eraser was our friend. I loved my pencil. I loved my eraser. I loved Mrs. Esselinger as she gave me the letters of my names, the first name and the last. I took possession of my letters. They were mine. I loved them like I loved Mrs. Esselinger. Except I learned to hate the letter S. My S snaked its way between me and Mrs. Esselinger and hissed its way into her heart. "But that's a Z," she said. "That's not an S. That's not one of your letters."

"I can't explain it. Your daughter doesn't know how to write."

"But of course she knows how to write," said my mother at last. 
"No, no she doesn't. She won't write. She sits there, pencil in hand, and will not write. I've tried and tried with her. She will not."

"But," my mother said, "how is it, if she doesn't know how to write, that she's written her name all over our furniture and our walls? She's always writing."

Caught between the voiced $\mathrm{Z}$ and the unvoiced S, I had curled up into that unvoiced phoneme and stopped my hand.

I don't know this for sure, but they say the person who invented the eraser had human beings pretty well sized up. They also say that the person who invented the pencil also invented the eraser. This isn't true, of course. But like so many sayings, their truth lies not in the literal. Soft or pointed? Pointed or soft? Poised between the pointed and the soft I am tense. Tense between humility and hubris. Poised between what can be explained and what cannot. Between contrition and control. Between the hope of redemption written in an apology and the sting of omission in the thank you note that never arrives. The past is making the present tense. The future perfect is conditional on the declarative.

I want to write this story but I don't know how to write.

I do not know the sentences, the paragraphs, even the text.

I know the punctuation.

In the stop of my hand I know the halting momentum of the curling pauses, the pointed stops, the vertical of the exclamatory, the curve of the interrogatory. I stop my hand lest the controlling indicative and the pride of the imperative refuse redemption in the subjunctive.

I do not know how to write. I do not know how to write this story. The protagonist won't come.'

(L. Lockford, Between the Pointed and the Soft, personal communication, May 26, 2011)

\section{There is No Conclusion...: Opening up the Art and Politics of Re-Presentation}

The reader must remember what it is I aim to present in this paper: simply a few minutes of a home-based literacy-related performance sandwiched in between other activities on a typical busy day, thus by no means the 'whole story'. The reader must remember that this interaction was selected to allow me to share/show how I enter the field - the jungle - of representing and making sense of the data. The reader must remember that this is an 'open' paper: the sharing of first impressions - ebullient, interwoven, organic - and a sharing of reflexive integrative or transdisciplinary creative, postmodern (auto)ethnographic methods in an attempt to get closer to, to enter the prism of, learning lived. Methodologically undergirded by a mélange of paradigms and analytical procedures relating to (various branches of) education, the social sciences, linguistics and philosophy, delineations that are constantly and increasingly in flux (Guba \& Lincoln, 2005), the paper is an evocation of experience; it is layered re-presentation, not explanation. Those expecting me to explain in full what I see taking place in the kitchen between mother and child (though I expand upon the drama which begins to unfurl in my own mind), those expecting me to steer their understanding in the 'right' direction, a goal research-speak traditionally sets itself, such people will no doubt feel short-changed.

The postmodernist context of doubt (...) does allow us to know 'something' without claiming to know everything (...) postmodernism 
recognizes the situational limitations of the knower (...) They do not have to try to play God, writing as disembodied omniscient narrators claiming universal and atemporal general knowledge. They can eschew the questionable metanarrative of scientific objectivity and still have plenty to say as situated speakers, subjectivities engaged in knowing/telling about the world as they perceive it. (Richardson \& St. Pierre, 2005, p. 961)

The good news is that the multiple selves - ourselves and our respondents - of postmodern inquiries may give rise to more dynamic, problematic, open-ended, and complex forms of writing. The bad news is that the multiple selves we create and encounter give rise to more dynamic, problematic, open-ended, and complex forms of writing. (Guba \& Lincoln, 2005, p. 210)

As I shrugged on my coat and threw my bags onto the passenger seat, it seemed to me that I had more questions than answers. Of course. I had spent not more than half an hour with Zoé at home, and had yet to embark upon the tricky business of analysing the data (congelation and coagulation of the fiery liquid or 'idioplasm'; Nietzsche, 1901/1967). Answers, or rather 'constructed understandings' (Travers Simon, 2010b), have come in due time, and they lead to... even more questions (venerable vs vulnerable... also: 'Wisdom never provides answers, it just redefines the questions', Dave Duncan in a private communication to Lesa Lockford, in Lockford, 2004, p.145). As I scatter these, then, my questions, before you, I sense discomfort; I feel weak, inoperative, courting embarrassment in the vanguard of stronger, more venerable discourse traditions. To write ethnography, to write this type of ethnography, is to write vulnerably (Lockford, 2004, citing someone else - who? Ruth Behar). I take comfort in two remarks made by Albert Einstein (brainy quotes, online), namely that a person who never made a mistake has never tried something new, and that it behoves us to look for what is (big dirty word coming from one who discovered relativity...) and not what we believe should be. So I continue in my attempts to see what there 'is' (are...); to replace assumptions/presumptions with observations. I continue to revisit my data, reinterpreting it in the light of my ongoing research. I continue to look: at children's and family domestic literacy practices, at institutional literacy practices, conducting multi-site ethnographic research on 'now' and 'then', forever seeking new ways to combine the findings into cogent pictures, 'stories', adapted to various audiences; the research community, trainee teachers, parents, children...(Writing with Pia: the first PhD thesis to be rewritten as a trilingual children's book. Bursch \& Simon, 2009).

Research: RE: again; SEARCH: look intensively: see; sea (data? interpretations/presumptions); sEARch 


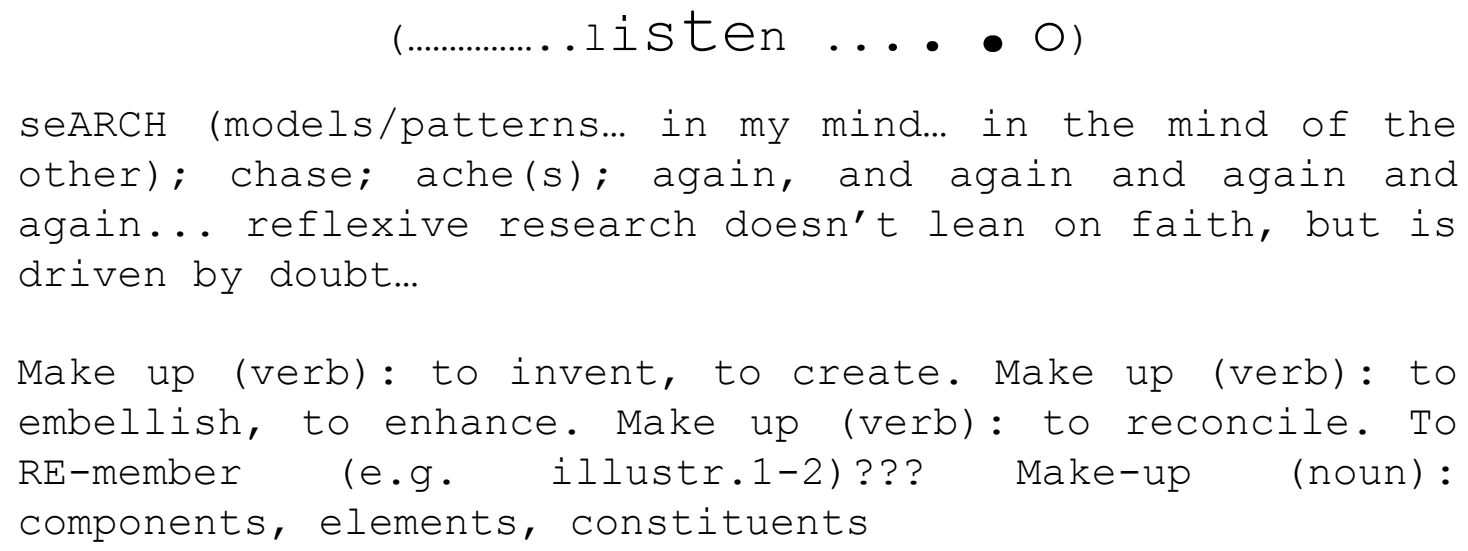

Make up (verb): to invent, to create. Make up (verb): to embellish, to enhance. Make up (verb): to reconcile. To RE-member (e.g. illustr.1-2) ??? Make-up (noun): components, elements, constituents

To learn is to make up...? To make up is to carve, to construct, discern, to 'wright' idiosyncratic paths from an infinite web of possibilities/components (anything learnt - as opposed to being natural - is unavailable to a finite description, see Stanley Fish, 2004). It is (is = 'old' language; Spivak (1974), in Richardson \& St. Pierre, 2005, p.968), it means to look intently, occasionally less so too, but certainly to be ready for surprises, or at the very least, to spot, to capture (some of) them when they arise, even if retrospectively, since to 'make up' entails more than just a forward feeding, linear process. It is, it appears to be a polychronic (moving at/in several different rates/directions), intertextual, bubbly/ing, messy and a potentially painful one. Much follows from such an approach to learning, foremost among which is to accept that to attempt to understand and learn from learning, and to write (perform) my reading of learning, entails abandoning measurables, discarding (post/positivist 'isomorphilic') product-driven orientations in favour of (postmodern/poststructralist, embodied, contiguous, contingent, temporalised, multi-directional, layered, organic) process-driven ones. To learn is to be in media res in the interminable flux of possibility, thus to wish to tell the story of learning means to tell a neverending story at a particular cross-section of time and place. To tell this story is an exercise in humility. It means refusing to proffer or guarantee with our accounts a peace of mind, merely to deliver pieces of mind/s; subjective interpretations, representations, narratives re-membered, whose openly acknowledged vulnerability may indeed be their greatest strength for they ensure that we keep looking. On this note, I invite you, the reader, to keep looking too; to combine, conflate, compare, temporal, linguistic, local, cultural, analytical, methodological performances, and to tell me what you see. 


\section{References}

Alexander, B. K. (2005). Performance ethnography. In N. K. Denzin \& Y. S. Lincoln (Eds.), The SAGE handbook of qualitative research (3rd ed., pp. 411-441). London, UK: Sage.

Bakhtin, M. (1981). The dialogic imagination: Four essays by M. M. Bakhtin. In M. Holquist (Ed.). (C. Emerson \& M. Holquist, Trans.). Austin, TX: University of Texas Press.

Bahktin, M. (1986). Speech genres and other late essays. Austin, TX: University of Texas Press.

Barton, D., \& Hamilton, M. (Eds.). (2000). Situated literacies: Reading and writing in context. London, UK: Routledge.

Bernstein, R. (1989). Social theory as critique. In D. Held \& J. B. Thompson (Eds.), Social theory of modern societies: Anthony Giddens and his critics (pp. 19-33). Cambridge, NY: Cambridge University Press.

Bourdieu, P. (1991). Language and symbolic power. J. B. Thompson (Ed.). (G. Raymond \& M. Adamson, Trans.). Cambridge, UK: Polity Press.

Bourdieu, P. (1993). The field of cultural production: Essays on art and literature. R. Johnson (Ed.). Cambridge: Polity Press.

Brown, S., \& Vaughan, C. (2009). Play: How it shapes the brain, opens the imagination and invigorates the soul. New York, NY: Avery.

Bronfenbrenner, U. (1979). The ecology of human development. Cambridge, MA: Harvard University Press.

Bruner, J. (1966). On cognitive growth, I and II. In J. Bruner, R. Olver, \& P. M. Greenfield (Eds.), Studies in cognitive growth (pp. 1-29, 30-67). New York, NY: Wiley and Sons.

Bruner, J. (1991). The narrative construction of reality. Critical Inquiry, 18(1), 2-21.

Bruner, J. (1999). Infancy and culture: A story. In S. Chaiklin, M. Hedegaard, \& U.J. Jensensen (Eds.), Activity theory and social practice (pp. 225-233). Oxford, UK: Aarhus University Press.

Bruner, J. (1990). Acts of meaning. Cambridge, MA: Harvard University Press.

Buklijas, T, \& Hopwood, N. (2008-2010). Making visible embryos. Retrieved from http://www.hps.cam.ac.uk/visibleembryos/s1_5.html

Bursch, J. (2005). Language patterns in a trilingual household. Bilingual Family Newsletter, 23(5), 6-7.

Bursch, J. (2008). Pia in France. In E. Gregory (Ed.), Learning to read in a new language: Making sense of words and worlds (pp. 35-40). London, UK: Sage.

Bursch, P., \& Simon, J. B. (2009). Writing with Pia. Birmingham, UK: Step Out Creatives.

Caminada, M. (2004). For the sake of the argument. Explorations into argumentbased theories. Unpublished doctoral dissertation, Free University Amsterdam, Netherlands.

Caminada, M. (2008). A formal account of Socratic-style argumentation. Journal of Applied Logic, 6(1). 109-132.

Caputo, J. (1997). (Ed.). Deconstruction in a nutshell: A conversation with Jacques Derrida. New York, NY: Fordham University Press.

Cixous, H., \& Clément, C. (1986). The newly born woman. (B. Wing, Trans.). London, UK: University of Minnesota Press.

Clay, M. (1991). Becoming literate: The construction of inner control. Auckland, New Zealand: Heinemann. 
Cole, M. (1998). Culture in development. In M. Woodhead, D. Faulkner, \& K. Littleton (Eds.), Cultural worlds of early childhood (pp. 11-33). London, UK: Routledge/the Open University.

Cummins, J. (2006). Identity texts: The imaginative construction of self through multiliteracies pedagogy. In O. Garcia, T. Skutnabb-Kangas \& E. Torres-Guzman (Eds.), Imagining multilingual schools: Languages in education and glocalization (pp. 51-68). Clevedon, UK: Multilingual Matters.

Czerniewska, P. (1992). Learning about writing. Oxford, UK: Blackwell.

Denzin, N. K., \& Lincoln, Y. S. (Eds.). (2005). The SAGE handbook of qualitative research (3rd ed.). London, UK: Sage.

Derrida, J. (1996). Le monolinguisme de l'autre. Paris, FR: Gallilée.

Derrida, J. (1976). Of grammatology. (G. C. Spivak, Trans.). Baltimore, MD: Johns Hopkins University Press.

De Saussure, F. (1983). Course in general linguistics. (R. Harris, Trans.). London, UK: Duckworth. (Original work published 1916).

Dockett, S. \& Perry, B. (2007). Trusting children's accounts in research. Journal of Early Childhood Research, 5(1), 47-63.

Dyson, A. H. (1993). Social worlds of children learning to write in an urban primary school. New York, NY: Teachers College Press.

Dyson, A. H. (1994). The value of 'Time Off' task: Young children's spontaneous talk and deliberate text. In B. Stierer \& J. Maybin (Eds.), Language, literacy and learning in educational practice (pp. 203-222). Clevedon, UK: Multilingual Matters.

Dyson, A. H. (2000). Linking writing and community development through the children's forum. In C. D. Lee \& P. Smargorinsky (Eds.), Vygotskian perspectives on literacy research: Constructing meaning through collaborative enquiry (pp. 127-149). Cambridge, NY: Cambridge University Press.

Dyson, A. H. (2001). Where are the children in childhood literacy? An exploration of (outer) space. Journal of Early Childhood Literacy, 1(1), 9-39.

Dyson, A. H. (2007). Literacy 'basics' in childhood spaces: A critical perspective on the 'basics'. In Y. Goodman \& P. Martens (Eds.), Critical issues in early literacy (pp. 153-173). London, UK: Lawrence Erlbaum Associates.

Einstein, A. Retrieved from http://www.brainyquote.com/quotes/authors/

Engeström, Y. (1999). Activity theory and individual social transformation. In Y. Engeström, R. Meittinen, \& R.-L. Punamaki (Eds.), Perspectives on activity theory (pp.19-38). Cambridge, NY: Cambridge University Press.

Engeström, Y. (2001). Expansive learning at work: Toward an activity theoretical reconceptualization. Journal of Education and Work, 14(1), 133-156.

Fereirro, E. (2007). Letters and numbers in early literacy. In Y. Goodman \& P. Martens (Eds.), Critical issues in early literacy (pp. 59-77). London, UK: Lawrence Erlbaum Associates.

Ferreiro, E. \& Teberosky, A. (1982). Literacy before schooling. Exeter, NH: Heinemann.

Fischer, K. W., \& Bidell, T. R. (1998). Dynamic development of psychobiological structures in action and thought. In R. M. Lerner (Ed.), Handbook of child psychology: Theoretical models of human development (5th ed., Vol.1, 467561). New York, NY: Wiley \& Sons.

Fish, S. (2004). Interpretive communities. In J. Rivkin \& M. Ryan (Eds.), Literary theory: An anthology (2nd ed., pp.217-221). London, UK: Blackwell. 
Fox. C. (2003). Playing the storyteller: some principles for learning literacy in the early years of schooling. In N. Hall, J. Larson, \& J. Marsh, (Eds.), Handbook of early childhood literacy (pp. 189-198). London, UK: Sage.

Frisch, R. (1997). Am Anfang war die Tat (Goethe). Der Mensch als Schöpfer. Der schöpferische Prozess, eine auf andere bezogene Tätigkeit, in DECOLAP - A l'écoute des enfants. Luxembourg: MENFP/SCRIPT.

Gee, J. P. (1994). Orality and literacy: From the savage mind to ways with words. In J. Maybin (Ed.), Language and literacy in social practice (pp. 168-192). Clevedon, UK: Multilingual Matters.

Gee, J. P. (2000). New people in new worlds. In S. Goodman, T. Lillis, J. Maybin, \& N. Mercer (Eds.), Language, literacy and education: A reader (pp.43-68). Stoke-on-Trent, UK: Trentham.

Gee, J. P. (2004). Situated language and learning. A critique of traditional schooling. New York, NY: Routledge.

Gee, J. P. (2005a). Semiotic social spaces and affinity spaces: From the age of mythology to today's schools. In D. Barton \& K. Tusting (Eds.), Beyond communities of practice: Language, power and social context (pp. 214-232). New York, NY: Cambridge University Press.

Gee, J. P. (2005b). Critical discourse analysis. In R. Beach, J. Green, M. Kamil, \& T. Shanahan, (Eds.), Multidisciplinary perspectives on literacy research (2nd ed., pp. 293-318). Cresskill, NJ: Hampton Press, Inc.

Gee, J. P. (2008). Social linguistics and literacy (2nd ed.). London, UK: Routledge.

Goelman, H., Oberg, A., \& Smith, F. (Eds.). (1984). Awakening to literacy. London, UK: Heinemann.

Goodman, Y. (2007). Documenting critical literacy development in classrooms. In Y. Goodman \& P. Martens (Eds.), Critical issues in early literacy (pp. 83-95). London, UK: Lawrence Erlbaum Associates.

Gottlieb, G., Wahlsten, D. \& Lickliter, R. (1998). The significance of biology for human development: A developmental psychobiological systems view. In R. M. Lerner (Ed.), Handbook of child psychology: Theoretical models of human development (5th ed., Vol.1, 233-273). New York, NY: Wiley \& Sons, Inc.

Guba, E. G., \&Lincoln, Y. S. (2005). Paradigmatic controversies, contradictions, and emerging confluences. In N. K. Denzin, \& Y. S. Lincoln, (Eds.), The SAGE handbook of qualitative research (3rd ed., pp.191-215). London, UK: Sage.

Hall, N., Larson, J., \& Marsh, J. (Eds.). (2003). Handbook of early childhood literacy. London, UK: Sage Publications.

Hill, L. (2007). The Cambridge introduction to Jacques Derrida. Cambridge, MA: Cambridge University Press.

Hoogsteder, M, Maier, R. \& Elbers, E. (1998). Adult interaction, joint problem solving and the structure of cooperation. In M. Woodhead, D. Faulkner, \& K. Littleton (Eds.), Cultural worlds of early childhood (pp. 178-195). London, UK: Routledge/The Open University.

Ivanič, R. (2004). Discourses of writing and learning to write. Language and Education, 18(3), 220-245.

Kress, G. (1994). Learning to write (2nd ed.). London, UK: Routledge.

Kress, G. (1997). Before writing; Rethinking the paths to literacy. London, UK: Routledge. 
Kress, G. (2003). Perspectives on making meaning: The differential principles and means of adults and children. In N. Hall, J. Larson, \& J. Marsh (Eds.), Handbook of early childhood literacy (pp.154-168). London, UK: Sage.

Lahman, M. K. E. (2008). Always othered: Ethical research with children. Journal of Early Childhood Research, 6(3), 281-300.

Lave, J. \& Wenger, E. (1991). Situated learning: Legitimate peripheral participation. New York, NY: Cambridge University Press.

Lemke, J. (1994). Semiotics and the deconstruction of conceptual learning. Retrieved from http://www-personal.umich.edu/ jaylemke/papers/jsalt.htm

Lemke, J. (2004). Learning across multiple places and their chronotopes. Paper presented at the meeting of American Educational Research Association (AERA) 2004 Symposium: Spaces and Boundaries of Learning. Retrieved from http://www-personal.umich.edu/ jaylemke/papers/aera_2004.htm

Light, P. \& Littleton, K. (1998). Cognitive approaches to group work. In D. Faulkner, K. Littleton, \& M. Woodhead (Eds.), Learning relationships in the classroom (pp. 171-188). London, UK: Routledge.

Lockford, L. (2004). Performing femininity: Rewriting gender identity. Walnut Creek, CA: Altamira Press.

Magnusson, D., \& Stattin, H. (1998). Person-context interaction theories. In R. M. Lerner (Ed.), Handbook of child psychology: Theoretical models of human development (5th ed., Vol.1, 685-759). New York, NY: Wiley \& Sons.

Martinez, M., Roser, N., \& Dooley, C. (2003). Young children's literary meaning making. In N. Hall, J. Larson, \& J. Marsh (Eds.), Handbook of early childhood literacy (pp. 222-234). London: Sage.

Mercer, N. (1995). The guided construction of knowledge. Clevedon, UK: Multilingual Matters.

Mercer. N., \& Littleton, K. (2007). Dialogue and development of children's thinking: A sociocultural approach. London, UK: Routledge.

Mininni, G. (2008). What is it like to be a person? The contribution of discursive psychology to idiographic science. In S. Salvatore, J. Valsiner, S. Strout, \& J. Clegg (Eds.), YIS: Yearbook of ideographic science, 1, 249-271.

Nietzsche, F. (1968). The will to power. With facsimiles of the original manuscript. W. Kaufman (Ed.). (W. Kaufmann \& R. J. Hollindale, Trans.). Westminster, MD: Random House.

Nietzsche, F. (2004). The will to power. In J. Rivkin \& M. Ryan (Eds.) Literary theory: An anthology (2nd ed., pp. 266-270). London, UK: Blackwell.

Nietzsche, F. (1873). On truth and lies in an extra-moral sense, (W. Kaufmann \& D. Breazeale, Trans.).

Retrieved from http://www.geocities.com/thenietzschechannel/tls.htm.

Paley, V. (1990). The boy who would be a helicopter. Cambridge, MA: Harvard University Press.

Paley, V. (1997). The girl with the brown crayon. Cambridge, MA: Harvard University Press.

Rich, A. (1979). On lies, secrets, and silences: Selected prose 1966-1978. New York, NY: Norton.

Richardson, L., \& St. Pierre, E.A. (2005). Writing: A method of inquiry. In N. K. Denzin \& Y. S. Lincoln (Eds.), The SAGE handbook of qualitative research (pp. 959-978). Thousand Oaks, CA: Sage. 
Rogoff, B. (1990). Apprenticeship in thinking: Cognitive development in social context. Oxford, UK: Oxford University Press.

Russell, B. (2008). The analysis of mind: Twenty-five lectures by Bertrand Russell. Rockville, MD: Arc Manor.

Säljö, R. (1998). Thinking with and through artifacts: The role of psychological tools and physical artifacts in human learning and cognition. In D. Faulkner, K. Littleton, \& M. Woodhead (Eds.), Learning relationships in the classroom (pp. 54-66). London, UK: Routledge.

Sato, T., Hidaka, T., \& Fukuda, M. (2009). Depicting the dynamics of living the life. In J. Valsiner, P. Molenaar, M. Lyra, \& N. Chaudhary (Eds.), Dynamic process methodology in the social and developmental sciences (pp. 17-24). New York, NY: Springer.

Scheurich, J. J., \& McKenzie, K. B. (2005). Foucault's methodologies: Archaeology and geneaology. In N. K. Denzin \& Y. S. Lincoln (Eds.), The SAGE handbook of qualitative enquiry (pp. 841-868). Thousand Oaks, CA: Sage.

Stake, R. (2005). Qualitative case studies. In N. K. Denzin \& Y. S. Lincoln (Eds.), The SAGE handbook of qualitative research (pp. 443-466). Thousand Oaks, CA: Sage.

Stoler, A. L. (1995). Race and the education of desire. Foucault's history of sexuality and the colonial order of things. London, UK: Duke University Press.

Street, B. (1984). Literacy in theory and practice. New York, NY: Cambridge University Press.

Street, B. (Ed.). (1993). Cross cultural approaches to literacy. Cambridge, MA: Cambridge University Press.

Street, B. (1995). Social literacies: Critical approaches to literacy in development, ethnography and education. London, UK: Longman.

Street, B. (1998). Literacy in theory and practice. Cambridge, MA: Cambridge University Press.

Street, B. (2000). Literacy events and literacy practices: Theory and practice in New Literacy Studies. In M. Martin-Jones \& K. Jones (Eds.), Multilingual literacies: Reading and writing different worlds (pp. 17-29). Amsterdam, PA: John Benjamin Publishing.

Street, B. (Ed.). (2001). Literacy and development: Ethnographic practices. London, UK: Routledge.

Street, B. (2003). The implications of the 'New Literacy studies' for literacy education. In S. Goodman, T. Lillis, J. Maybin, \& N. Mercer (Eds.), Language, literacy and education: A reader (pp.77-88). Stoke-on-Trent, UK: Trentham.

Street, B. (2004). Futures of the ethnography of literacy. Language and Education, 18(4), 326-330.

Street, B., \& Hornberger, N. (Eds.). (2008). Encylopedia of language and literacy (Vol. 2). New York, NY: Springer.

Taylor, S. (Ed.). (2002). Ethnographic research: A reader. Thousand Oaks, CA: Sage.

Travers Simon, J. B. (2010a). Mind the gap: The domestic writings of a child practitioner and their implications for educational practice. Saarbrücken, DE: Lambert Academic Publishing.

Travers Simon, J. B. (2010b). Modelling learning: An empirical transdisciplinary approach. Saarbrücken, DE: Lambert Academic Publishing. 
Trifonas, P. (2004). The ethics of science and/as research: Deconstruction and the orientations of a new academic responsibility. In P. P. Trifonas \& M. A. Peters (Eds.), Derrida: Deconstruction and education: Ethics of pedagogy and research (pp.31-41). Oxford, UK: Blackwell.

Valsiner, J. (1997). Culture and the development of children's actions; A theory of human development (2nd ed.). New York, NY: John Wiley and Sons.

Valsiner, J. (2007). Returning to the future of psychology: Cultural psychology and the study of mental self-regulatory processes. Intellectica, 2-3(46-47), 251-268.

Van Lier, L. (1996). Interaction in the language curriculum: Awareness, autonomy \& authenticity. London, UK: Longman.

Van Lier. L. (2004). The ecology and semiotics of language learning. Norwell, MA: Kluwer Academic Publishers.

von Bertalanffy, L. (1962). Modern theories of development: An introduction to theoretical biology. New York, NY: Harper.

Vygotsky, L. (1978). Mind in Society: The development of higher psychological processes. Cambridge, MA: Harvard University Press.

Wertsch, J. V. (1991). Voices of the mind: A sociocultural approach to mediated action. Cambridge, MA: Harvard University Press.

Whitehead, M. R., (1997). Language and literacy in the early years (2nd ed.). London, UK: Paul Chapman Publishing.

Wood, D. (1998). How children think and learn (2nd ed.). Oxford, UK: Blackwell.

\section{Author Biography}

Joan Travers Simon is postdoctoral researcher in the Faculty of Language and Literature, Humanities, Arts and Education at the University of Luxembourg. Her research interests include plurilingualism, cognitive development, early domestic literacy practices and institutional literacy in multicultural contexts.

\section{Endnotes}

\footnotetext{
i As 'staged re-enactments' or 'body-centered method of knowing' (Alexander 2005, p.411) the transcription of family interaction and the thought chains presented in this paper may be interpreted as performances soliciting the 'participatory viewing' of the audience (Alexander 2005, p.420). Indeed, all forms of writing are performative

${ }^{\text {ii }}$ For the similarities in structure and intent between the vignettes presented here, my performance of reflexivity and the narrative enquiry branch of qualitative research, see Chase 2005

iii Various scholars cited are merely indicative of where I shall begin to look to further my understanding. A number of them are not cited for having already informed the current paper and thus do not appear in the bibliography
} 